\title{
OmniaScience
}

\section{Número especial:}

\section{Jornada ACCID I APC}

\author{
Joaquim Rabaseda Tarrés (iD
}

President de l'Agrupació de Professors de Comptabilitat i Control i Membre de la Junta Directiva de l'ACCID (Spain) joaquim.rabaseda@udg.edu

Received October, 2016

Accepted December, 2016

Novament, la revista Intangible Capital cedeix les seves pàgines per recollir en un número especial treballs de recerca sobre comptabilitat i direcció d'empreses procedents d'un esdeveniment celebrat en l'àmbit de l'ACCID. En aquest cas, els textos han estat seleccionats per la pròpia revista entre els que es van presentar en la IV Jornada ACCID i APC.

La Jornada se celebra cada dos anys, concretament en els anys en què no hi ha congrés. L'interès d'aquestes trobades resideix en el fet de mantenir contacte de forma continuada entre professionals $\mathrm{i}$ acadèmics, així com possibilitar la presència de l'Associació en els diferents indrets que configuren la geografia catalana. Aquesta última edició es va celebrar a la Universitat de Lleida, el passat 27 de maig de 2016 i va comptar amb un nombre d'inscrits que s'acosta als quatre-cents. La temàtica central s'ha centrat en la informació financera i la recuperació econòmica.

Els treballs que es presenten en aquest número de la revista són originals i van ser presentats en les deu sessions que es van celebrar en la jornada abans esmentada. Per la seva selecció, van haver de passar un procés de revisió per part del Comitè Científic de la Jornada i pel Comitè Editorial de la revista. 
Cada un dels vuit treballs que es presenten toca una temàtica diferent $\mathrm{i}$ aporta nous coneixements en el camp de la Comptabilitat i la Direcció d'empreses. A continuació es presenta una breu descripció de cada un d'ells.

El primer article posa l'accent en la contraposició entre les empreses familiars i les que no ho són, comparant la diferència en la distribució del valor afegit. Així mateix, també s'analitza la productivitat dels diferents factors relacionant el seu cost amb la riquesa generada.

El segon pretén determinar l'efectivitat dels mecanismes de control intern i esbrinar si hi ha evidència de conflictes entre la propietat i els gestors. També es busca delimitar com els controls interns afecten al risc de crèdit.

En el tercer es desenvolupa un model de puntuació que es pugui utilitzar per predir problemes de solvència. I s'ofereix la seva validació mitjançant l'estudi de dues mostres diferents, posant de manifest el poder predictiu que pot ser utilitzat per detectar deficiències en base a quatre ràtios.

En el quart treball es fa una revisió de la literatura que existeix sobre l'aportació de la seguretat operacional en el sector aeri, a partir de la literatura acadèmica internacional que hi ha dins l'àmbit de les ciències socials.

El cinquè article presenta una anàlisi del desenvolupament, implementació i ús dels diferents sistemes de costos en les diferents universitats.

El següent treball, el sisè, s'ocupa d'una problemàtica empresarial nova. Es presenta un estudi sobre l'existència de la relació entre la presència de l'Airbnb i els seus efectes en els ingressos i resultats dels hotels, a partir d'una anàlisi del sector hoteler de Barcelona.

També relacionat amb la problemàtica hotelera, el setè article se centra en el càlcul dels costos dels hotels, es fa una avaluació i interpretació del grau de necessitat percebuda pels agents directius del sector, del que s'anomena un moviment uniformista a la espanyola. S'intenta donar resposta a la qüestió de si s'han d'acceptar les propostes professionals disponibles, o bé cal crear-ne una de pròpia.

I l'últim treball s'ocupa d'un fet històric relacionat amb la nostra disciplina, com és la celebració del VIè Congrés Internacional de Comptabilitat, que va tenir lloc a Barcelona l'any 1929, dins el context dels congressos internacionals de comptabilitat que hi va haver a Europa entre els anys 1910 i 1939. Es presenta una descripció de l'organització del congrés de Barcelona, el seu desenvolupament i les conclusions que s'hi varen extreure. 
Tots aquests són els treballs que es presenten en el present número de la revista, tot esperant que siguin d’interès per als lectors i més endavant la seva lectura els pugui resultar d’utilitat.

Intangible Capital, 2017 (www.intangiblecapital.org)

Article's contents are provided on an Attribution-Non Commercial 3.0 Creative commons license. Readers are allowed to copy, distribute and communicate article's contents, provided the author's and Intangible Capital's names are included. It must not be used for commercial purposes. To see the complete license contents, please visit http://creativecommons.org/licenses/by-nc/3.0/. 